\title{
PENGARUH WAKTU PERENDAMAN BASIS GIGITIRUAN RESIN AKRILIK POLIMERISASI PANAS DALAM EKSTRAK BUAH LERAK 0,01\% TERHADAP KEKUATAN IMPAK
}

\author{
(EFFECTS OF SOAKING TIME HEAT-CURED ACRYLIC DENTURE BASE RESIN \\ IN 0,01\% LERAK EXTRACT TOWARDS THE IMPACT STRENGTH)
}

\author{
Ricca Chairunnisa, Sunny Chailes \\ Departemen Prostodonsia \\ Fakultas Kedokteran Gigi, Universitas Sumatera Utara \\ JL. Alumni No. 2 Kampus USU Medan 20155
}

\begin{abstract}
Acrylic denture can give a new problem to the patient if their oral hygiene and denture hygiene didn't get a good care. The most common problem is the increasing number of Candida albicans which can cause denture stomatitis. To prevent that problem, the acrylic denture must be cleaned by denture cleanser. The $0,01 \%$ lerak extract is proved to be effective to inhibit the growth of Candida albicans. The study aimed is to find how long the acrylic resin can be soaked in the $0,01 \%$ lerak extract which had no effect on decreasing the impact strength of acrylic resin. This research was experimental laboratory research using acrylic resin. The sample was divided into 10 groups. Group A, B, C, D, E acrylic resin was soaked in aquadest and group F, G, H, I, J acrylic resin was soaked in $0,01 \%$ lerak extract for 2, 3, 4, 5 and 7 days. Then impact strength of the samples was tested. There were significant differences of the impact strength between acrylic plates soaked in the aquadest and in 0,01\% lerak extract for 2, 3, 4, 5 and 7 days. In conclusion, $0,01 \%$ lerak extract reduced the impact strength of acrylic resin.
\end{abstract}

Key words: acrylic resin, impact strength, $0,01 \%$ lerak extract

\begin{abstract}
Abstrak
Gigitiruan berbasis akrilik dapat menimbulkan masalah baru bagi pasien jika kebersihan rongga mulut dan gigitiruan tidak terjaga. Masalah yang paling umum terjadi yaitu meningkatnya jumlah Candida albicans yang dapat menyebabkan denture stomatitis. Untuk mencegah hal tersebut, gigitiruan berbasis akrilik harus dibersihkan dengan bahan pembersih gigitiruan. Ekstrak lerak 0,01\% terbukti efektif menghambat pertumbuhan Candida albicans. Penelitian ini bertujuan untuk mengetahui berapa lama resin akrilik dapat direndam dalam ekstrak lerak $0,01 \%$ dan tidak berpengaruh pada penurunan kekuatan impak resin akrilik. Penelitian ini menggunakan metode eksperimental laboratoris dengan bahan resin akrilik. Sampel dibagi menjadi 10 kelompok. Resin akrilik kelompok A,B,C,D,E direndam dalam akuades dan kelompok F,G,H,I,J direndam dalam ekstrak lerak 0,01\% selama 2,3,4,5 dan 7 hari. Setelah itu, kekuatan impak dari sampel diuji. Hasil penelitian menunjukkan terdapat perbedaan signifikan kekuatan impak resin akrilik yang direndam dalam akuades dan ekstrak lerak 0,01\% selama 2,3,4,5 dan 7. Sebagai kesimpulan, ekstrak lerak 0,01\% menurunkan kekuatan impak resin akrilik.
\end{abstract}

Kata Kunci : resin akrilik, kekuatan impak, ekstrak lerak 0,01\%

\section{PENDAHULUAN}

Resin akrilik polimerisasi panas (RAPP) merupakan bahan yang paling banyak digunakan dalam pembuatan basis gigitiruan. ${ }^{1}$ Permukaan resin akrilik yang menghadap ke jaringan rongga mulut biasanya terdapat celah mikro. Dengan adanya saliva dapat membentuk pelikel dan menyebabkan sisa makanan, plak, mikroorganisme dan Candida albicans mudah menempel pada gigitiruan sehingga mengakibatkan terjadinya denture stomatitis., ${ }^{2,3} \mathrm{Hal}$ tersebut dapat dicegah dengan membersihkan gigitiruan secara rutin. ${ }^{4}$ Buah lerak (Sapindus rarak) dapat menjadi alternatif bahan pembersih gigitiruan 
karena memiliki efek anti jamur dan antibakteri. ${ }^{5}$ Kandungan utama buah lerak yaitu saponin, merupakan senyawa aktif sebagai deterjen dan bahan pembersih gigitiruan. ${ }^{6,7}$ Hasil penelitian Namira menunjukkan bahwa kelompok bahan pembersih ekstrak buah lerak lebih efektif daripada klorheksidin glukonat terhadap jumlah Candida albicans. ${ }^{8} \mathrm{Na}-$ mun, buah lerak mengandung fenol yang dapat mempengaruhi sifat mekanis gigitiruan. Flavonoid merupakan golongan terbesar dari senyawa fenol. Shen menyatakan bahwa polifenol berkontak dengan lempeng akrilik akan bereaksi dengan ester dari polimetil metakrilat dalam lempeng resin akrilik. Ikatan rantai polimer dari resin akrilik menjadi terganggu sehingga mengakibatkan sifat fisis lempeng akrilik semakin melemah dan mengakibatkan permukaannya menjadi lunak sehingga sebagian resin akrilik larut, yang apabila ini terus-menerus terjadi akan membentuk pori-pori pada permukaan resin akrilik dan dapat menurunkan kekuatan impak., ${ }^{9,10}$

Kekuatan impak menurut Anderson yaitu daya tahan suatu bahan agar tidak patah bila mendapat daya yang besar dan tiba-tiba dalam bentuk tension dan compression. ${ }^{11}$ Nilai kekuatan impak minimal basis gigitiruan RAPP adalah $5 \mathrm{KJ} / \mathrm{m}^{2}{ }^{12}$ Anusavice ${ }^{9}$ menyatakan bahwa penurunan kekuatan impak dari resin akrilik juga disebabkan oleh penyerapan zat cair secara difusi oleh RAPP. Molekul air mengakibatkan ikatan polimer terpisah sehingga mempengaruhi kekuatan rantai polimer dan molekul air juga berperan sebagai plasticizer sehingga menyebabkan penurunan kekuatan impak. ${ }^{9}$ Sari dkk. ${ }^{10}$ menyatakan bahwa senyawa flavonoid dalam larutan propolis dapat menurunkan kekuatan impak RAPP selama 8 , 16, 32 dan 64 jam. ${ }^{10}$ Handayani dkk., menyatakan bahwa flavonoid dalam cabai rawit dapat menurunkan kekuatan impak RAPP selama 1, 6 dan 18 hari. ${ }^{13}$ Pemakaian ekstrak buah lerak yang efektif adalah dengan merendam gigitiruan selama 5 menit setiap hari, sedangkan pemakaian gigitiruan yang ideal yaitu selama 3-5 tahun. ${ }^{3,8}$ Dari perhitungan didapatkan 2 hari perendaman identik dengan pemakaian selama 1 tahun, 3 hari identik dengan 2 tahun, 4 hari identik dengan 3 tahun, 5 hari identik dengan 4 tahun dan 7 hari identik dengan 5 tahun dan konsentrasi ekstrak buah lerak yang digunakan adalah $0,01 \%$ karena konsentrasi tersebut memberi efek antifungal terhadap Candida albicans. ${ }^{8}$ Berdasarkan hal tersebut, perlu diteliti apakah ada pengaruh waktu perendaman basis gigitiruan RAPP dalam ekstrak buah lerak $0,01 \%$ selama $2,3,4,5$ dan 7 hari terhadap kekuatan impak.

Tujuan penelitian ini adalah untuk mengetahui pengaruh waktu perendaman basis gigitiruan RAPP dalam ekstrak buah lerak 0,01\% selama 2, 3, 4, 5 dan 7 hari terhadap kekuatan impak. Manfaat penelitian ini adalah diharapkan agar penelitian lebih banyak diarahkan untuk memperkuat bahan basis gigitiruan RAPP.

\section{BAHAN DAN METODE}

Penelitian ini merupakan penelitian eksperimental laboratoris dengan desain post test only control group.

Pembuatan ekstrak buah lerak dengan cara buah lerak dicuci, dipotong, dibuang bijinya, ditimbang sebanyak 300 gram, dikeringkan sampai dapat diremas rapuh (simplisia), dihaluskan dengan blender lalu diayak. Sebanyak 30 gram simplisia direndam dalam $300 \mathrm{ml}$ etanol $70 \%$ selama 24 jam, dipindahkan ke perkolator, ditambahkan etanol $70 \%$ sebanyak $200 \mathrm{ml}$ dan dibiarkan menetes dengan kecepatan \pm 20 tetes/menit. Pelarut dan ekstraknya dipisahkan dengan rotavapor sehingga diperoleh ekstrak kental. Pengenceran $10 \mathrm{mg}$ ekstrak kental dengan etanol $96 \%$ sampai volumenya $100 \mathrm{ml}$ sehingga diperoleh larutan ekstrak buah lerak $0,01 \%$.

Selanjutnya, pembuatan sampel dengan cara gips keras dan air dengan perbandingan 300 gram: $90 \mathrm{ml}$ diaduk selama 15 detik, masukkan ke dalam kuvet yang telah diolesi vaselin di atas vibrator. Setelah mengeras diolesi vaselin, kuvet atas disatukan dengan kuvet bawah, isi adonan gips di atas vibrator. Setelah mengeras, kuvet dibuka, model induk diangkat. Mold disiram dengan air panas sampai bersih. Setelah kering, permukaan gips keras pada kuvet bawah dan kuvet atas diolesi cold mould seal dan dibiarkan 20 menit.

Pengadukan polimer dan monomer dengan perbandingan $9 \mathrm{gr}: 4,5 \mathrm{ml}$ dalam pot porselen sampai mencapai dough stage, kemudian masukkan ke dalam mold kuvet bawah. Plastic selopan diletakkan diantara kuvet atas dan bawah, kuvet ditutup dan ditekan dengan pres hidrolik dengan tekanan 1000 psi. Kuvet dibuka dan kelebihan akrilik dipotong dengan lecron mass, lalu kuvet ditutup kembali. penekanan kedua dengan tekanan 2200 psi lalu baut dipasang. Selanjutnya kuring dengan suhu $70^{\circ} \mathrm{C}$ selama 90 menit lalu $100{ }^{\circ} \mathrm{C}$ selama 30 menit. Setelah itu dibiarkan hingga mencapai suhu kamar. Sampel dikeluarkan, kelebihan akrilik dibuang dengan bur fraser dan dihaluskan dengan kertas pasir waterproof ukuran 1000 dan diberi nomor pada kedua ujungnya. Sampel direndam dalam akuades selama 48 jam dan dibagi menjadi 10 kelompok, yaitu sampel yang direndam dalam akuades selama 2 hari (A), selama 3 hari (B), selama 4 hari (C), selama 5 hari (D), selama 7 hari (E), sampel yang direndam dalam ekstrak buah lerak $0,01 \%$ selama 2 hari (F), selama 
3 hari $(\mathrm{G})$, selama 4 hari $(\mathrm{H})$, selama 5 hari (I), selama 7 hari (J). pada hari ke 2 sampel direndam sesuai masing-masing kelompok. Setelah itu dibiarkan kering.

Pengukuran kekuatan impak menggunakan Amslerotto Walpret Werke GMBH, Germany dengan cara sampel diberi tanda pada bagian tengahnya, diletakkan pada posisi horizontal. Lengan pemukul dikunci kemudian dilepaskan hingga membentur sampel hingga fraktur, catat nilai yang terlihat pada alat pengukur.

Cara perhitungan kekuatan impak dengan rumus:

$$
\text { Kekuatan impak }=\underset{\mathrm{T} \times \mathrm{W}}{\mathrm{E}}
$$

Keterangan: $\mathrm{E}=$ energy $(\mathrm{KJ}), \mathrm{T}=$ ketebalan sampel $(\mathrm{m})$, $\mathrm{W}=$ lebar sampel $(\mathrm{m})$

Uji t, ANOVA satu arah dan LSD digunakan untuk mengetahui pengaruh waktu perendaman basis gigitiruan RAPP dalam larutan ekstrak buah lerak 0,01\% selama 2, 3, 4, 5 dan 7 hari terhadap kekuatan impak.

\section{HASIL}

Kekuatan impak basis gigitiruan RAPP setelah direndam dalam ekstrak buah lerak $0,01 \%$ lebih rendah daripada setelah direndam dalam akuades (Tabel 1).

Tabel 1. Kekuatan impak basis gigitiruan resin akrilik polimerisasi panas yang direndam dalam akuades (kontrol) dan ekstrak buah lerak $0,01 \%$ selama 2 hari, 3 hari, 4 hari, 5 hari dan 7 hari $\left(\mathrm{KJ} / \mathrm{m}^{2}\right)$

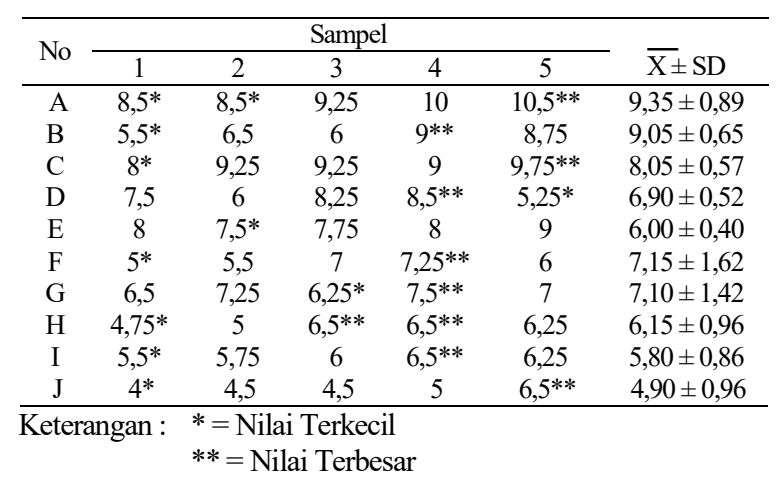

Hasil uji $\mathrm{t}$ menunjukkan adanya perbedaan yang signifikan, yaitu kelompok A dan F, B dan G, C dan $\mathrm{H}, \mathrm{D}$ dan I, E dan $\mathrm{J}(\mathrm{p}<0,05)($ Tabel 2).
Tabel 2. Perbedaan kekuatan impak basis gigitiruan resin akrilik polimerisasi panas pada perendaman dalam ekstrak buah lerak $0,01 \%$ dan kontrol pada masing-masing kelompok waktu

\begin{tabular}{cccc}
\hline $\begin{array}{c}\text { Larutan } \\
\text { perendaman }\end{array}$ & $\begin{array}{c}\text { Lama } \\
\text { perendaman }\end{array}$ & $\mathrm{n}$ & $\mathrm{P}$ \\
\hline A dan F & 2 hari & 5 & $0,036^{*}$ \\
B dan G & 3 hari & 5 & $0,034^{*}$ \\
C dan H & 4 hari & 5 & $0,005^{*}$ \\
D dan I & 5 hari & 5 & $0,046^{*}$ \\
E dan J & 7 hari & 5 & $0,046^{*}$ \\
\hline
\end{tabular}

Keterangan $: *=$ Signifikan

Hasil uji ANOVA satu arah menunjukkan adanya pengaruh yang signifikan waktu perendaman basis gigitiruan RAPP dalam ekstrak buah lerak 0,01\% selama 2, 3, 4, 5 dan 7 hari terhadap kekuatan impak $(\mathrm{p}<0,05)($ Tabel 3).

Tabel 3. Pengaruh waktu perendaman basis gigitiruan resin akrilik polimerisasi panas dalam ekstrak buah lerak $0,01 \%$ selama 2 hari, 3 hari, 4 hari, 5 hari dan 7 hari terhadap kekuatan impak

\begin{tabular}{cccc}
\hline Kelompok & $\mathrm{n}$ & $\mathrm{X} \pm \mathrm{SD}\left(\mathrm{KJ} / \mathrm{m}^{2}\right)$ & $\mathrm{P}$ \\
\hline $\mathrm{F}$ & 5 & $7,15 \pm 1,62$ & $0,039^{*}$ \\
$\mathrm{G}$ & 5 & $7,10 \pm 1,42$ & \\
$\mathrm{H}$ & 5 & $6,15 \pm 0,96$ & \\
$\mathrm{I}$ & 5 & $5,80 \pm 0,86$ & \\
$\mathrm{~J}$ & 5 & $4,90 \pm 0,96$ & \\
\hline
\end{tabular}

Keterangan: $*=$ Signifikan

Hasil uji LSD menunjukkan adanya perlakuan yang signifikan antar kelompok, yaitu kelompok $\mathrm{F}$ dan J, G dan J ( $\mathrm{p}<0,05)$ (Tabel 4).

Tabel 4. Perbedaan pengaruh waktu perendaman basis gigitiruan resin akrilik polimerisasi panas dalam ekstrak buah lerak $0,01 \%$ terhadap kekuatan $\operatorname{impak}\left(\mathrm{KJ} / \mathrm{m}^{2}\right)$

\begin{tabular}{lccc}
\hline Kelompok & & Mean difference & Sig \\
\hline $\mathrm{F}$ & $\mathrm{G}$ & 0,05 & 0,948 \\
& $\mathrm{H}$ & 1,00 & 0,203 \\
& $\mathrm{I}$ & 1,35 & 0,091 \\
$\mathrm{G}$ & $\mathrm{J}$ & 2,25 & $0,008^{*}$ \\
& $\mathrm{H}$ & 0,95 & 0,225 \\
& $\mathrm{I}$ & 1,30 & 0,102 \\
$\mathrm{H}$ & $\mathrm{J}$ & 2,20 & $0,009^{*}$ \\
& $\mathrm{I}$ & 0,35 & 0,650 \\
$\mathrm{I}$ & $\mathrm{J}$ & 1,25 & 0,115 \\
& $\mathrm{~J}$ & 0,90 & 0,250 \\
\hline
\end{tabular}

Keterangan : ${ }^{*}=$ Signifikan 


\section{PEMBAHASAN}

Hasil penelitian menunjukkan bahwa besarnya kekuatan impak bervariasi pada setiap sampel, hal ini disebabkan oleh beberapa faktor yang mempengaruhi proses pembuatan RAPP seperti teknik pengadukan, porositas, kandungan monomer sisa. Porositas internal yang tidak dapat dilihat secara kasat mata dapat menurunkan kekuatan RAPP. ${ }^{14}$

Nilai rerata dan SD kelompok A adalah 9,35 \pm $0,89 \mathrm{KJ} / \mathrm{m}^{2}$. Rerata dan SD kelompok B adalah 9,05 $\pm 0,65 \mathrm{KJ} / \mathrm{m}^{2}$. Rerata dan SD kelompok $\mathrm{C}$ adalah $8,05 \pm 0,57 \mathrm{KJ} / \mathrm{m}^{2}$. Rerata dan SD kelompok D adalah $6,90 \pm 0,52 \mathrm{KJ} / \mathrm{m}^{2}$. Rerata dan SD kelompok E adalah $6,00 \pm 0,40 \mathrm{KJ} / \mathrm{m}^{2}$. Rerata dan SD kelompok F adalah 7,15 $\pm 1,62 \mathrm{KJ} / \mathrm{m}^{2}$. Rerata dan SD kelompok $\mathrm{G}$ adalah $7,10 \pm 1,42 \mathrm{KJ} / \mathrm{m}^{2}$. Rerata dan SD kelompok H adalah $6,15 \pm 0,96 \mathrm{KJ} / \mathrm{m}^{2}$. Rerata dan SD kelompok I adalah 5,80 $\pm 0,86 \mathrm{KJ} / \mathrm{m}^{2}$. Rerata dan SD kelompok J adalah 4,90 $\pm 0,96 \mathrm{KJ} / \mathrm{m}^{2}$. Penelitian ini menunjukkan bahwa semakin lama waktu perendaman RAPP, semakin menurunkan kekuatan impak. Hal ini sesuai dengan pernyataan Anusavice ${ }^{9}$ bahwa penurunan kekuatan impak resin akrilik disebabkan oleh penyerapan zat cair secara difusi oleh RAPP. Molekul zat cair mengakibatkan ikatan polimer terpisah sehingga mempengaruhi kekuatan rantai polimer dan molekul air juga berperan sebagai plasticizer sehingga menyebabkan penurunan kekuatan impak dan semakin lama waktu perendaman, maka zat cair yang berdifusi ke dalam resin semakin banyak dan menyebabkan kekuatan impak semakin menurun. ${ }^{9}$ Nilai kekuatan impak pada kelompok F, G, H, I, J lebih rendah daripada kelompok A, B, C, D, E.(Tabel 1) Hal ini disebabkan karena adanya senyawa flavonoid dalam buah lerak. Soebagio ${ }^{15}$ menyatakan bahwa semakin lama waktu kontak resin akrilik dengan flavonoid, akan semakin menurunkan kekuatan impak resin akrilik tersebut. ${ }^{15}$

Hasil uji t pada Tabel 2 menunjukkan adanya perbedaan yang signifikan, yaitu kelompok $\mathrm{A}$ dan $\mathrm{F}$ dengan nilai $p=0,036(p<0,05)$, kelompok $B$ dan $G$ dengan nilai $\mathrm{p}=0,034(\mathrm{p}<0,05)$, kelompok $\mathrm{C}$ dan $\mathrm{H}$ dengan nilai $p=0,005(p<0,05)$, kelompok $D$ dan I dengan nilai $p=0,046(p<0,05)$, kelompok $E$ dan $J$ dengan nilai $p=0,046(p<0,05)$. Hasil penelitian ini sama dengan hasil penelitian yang dilakukan oleh Astuty ${ }^{16}$ yang melakukan perendaman RAPP dalam larutan cuka apel yang mengandung flavonoid (polifenol) menunjukkan adanya penurunan kekerasan permukaan RAPP. ${ }^{16}$ Hal tersebut disebabkan karena adanya senyawa flavonoid (polifenol) dalam ekstrak buah lerak. Resin akrilik bila berkontak dengan fenol akan menyebabkan kerusakan secara kimia pada permukaan resin akrilik dengan cara difusi, lalu timbul kekasaran pada permukaan resin akrilik sehingga menyebabkan retak (crazing) dan penurunan kekuatan impak serta kekerasan. Bila kekerasan resin akrilik menurun, maka kekuatan impak juga akan menurun. ${ }^{13}$ Polifenol jika berkontak dengan lempeng akrilik akan bereaksi dengan ester dari polimetil metakrilat dalam lempeng resin akrilik. Ikatan rantai polimer dari resin akrilik menjadi terganggu sehingga mengakibatkan sifat fisis lempeng akrilik semakin melemah karena senyawa tersebut akan masuk ke dalam permukaan resin akrilik dan mengakibatkan permukaannya menjadi lunak sehingga sebagian resin akrilik larut, yang apabila ini terusmenerus terjadi akan membentuk pori-pori pada permukaan resin akrilik dan dapat menurunkan kekuatan impak. ${ }^{9-10,15}$ Sedangkan pada akuades tidak mengandung zat yang dapat berinteraksi secara kimiawi dengan RAPP, sehingga terdapat perbedaan signifikan pada perendaman dalam akuades dan ekstrak buah lerak $0,01 \%{ }^{9}$

Hasil uji ANOVA satu arah pada Tabel 3 menunjukkan adanya pengaruh waktu perendaman basis gigitiruan RAPP dalam ekstrak buah lerak 0,01\% selama 2, 3, 4, 5 dan 7 hari terhadap kekuatan impak dengan nilai signifikansi $p=0,039(p<0,05)$. Hasil penelitian sesuai dengan penelitian yang dilakukan oleh Handayani dkk. yang melakukan perendaman RAPP dalam larutan cabai rawit yang mengandung flavonoid (polifenol) selama 1, 6 dan 18 hari. Hasil penelitian menunjukkan lama perendaman RAPP dalam larutan cabai rawit berpengaruh secara signifikan terhadap kekuatan impak terutama pada perlakuan lama perendaman selama 18 hari. Nilai rerata terkecil yang didapatkan dari peneltian tersebut yaitu sebesar $7,17 \mathrm{KJ} / \mathrm{m}^{2}$ pada perendaman dalam larutan cabai rawit selama 18 hari. ${ }^{13}$ Hasil yang diperoleh pada penelitian ini juga sama dengan hasil penelitian yang dilakukan oleh Susilaningtyas dkk. yang melakukan perendaman RAPP dalam ekstrak rosela 30\% yang mengandung flavonoid (polifenol) selama 48 dan 96 menit. Hasil penelitian menunjukkan lama perendaman RAPP dalam ekstrak rosela $30 \%$ berpengaruh terhadap penurunan kekuatan impak. Rerata kekuatan impak RAPP pada waktu perendaman 96 menit adalah $6,10 \mathrm{KJ} / \mathrm{m}^{2} .15$

Adanya perlakuan yang signifikan disebabkan karena adanya senyawa flavonoid (polifenol) yang terkandung dalam ekstrak buah lerak. Polifenol dapat bereaksi dengan resin akrilik. Polifenol jika berkontak dengan lempeng akrilik akan bereaksi dengan ester dari polimetil metakrilat dalam lempeng resin akrilik. Ikatan rantai polimer dari resin akrilik menjadi terganggu sehingga mengakibatkan sifat fisis lempeng akrilik semakin melemah karena senyawa tersebut akan masuk ke dalam permukaan resin akri- 
lik dan mengakibatkan permukaannya menjadi lunak sehingga sebagian resin akrilik larut, yang apabila ini terus-menerus terjadi akan membentuk poripori pada permukaan resin akrilik dan dapat menurunkan kekuatan impak. ${ }^{9-10,15}$ Resin akrilik bila berkontak dengan fenol akan menyebabkan kerusakan secara kimia pada permukaan resin akrilik dengan cara difusi, lalu timbul kekasaran pada permukaan resin akrilik sehingga menyebabkan retak (crazing) dan penurunan kekuatan impak serta kekerasan. Bila kekerasan resin akrilik menurun, maka kekuatan impak juga akan menurun. ${ }^{13}$

Nilai rerata kelompok $\mathrm{J}$ adalah $4,90 \pm 0,96 \mathrm{KJ} / \mathrm{m}^{2}$. Nilai ini lebih kecil dari nilai rerata hasil penelitian yang dilakukan oleh Handayani dkk. pada perendaman selama 18 hari, yaitu sebesar $7,17 \mathrm{KJ} / \mathrm{m}^{2}$. Nilai rerata kelompok I adalah $5,80 \pm 0,86 \mathrm{KJ} / \mathrm{m}^{2}$. Nilai ini lebih besar dari nilai rerata hasil penelitian yang dilakukan oleh Diansari dkk. pada perendaman selama 5 hari, yaitu sebesar 4,87 $\pm 0,145 \mathrm{KJ} / \mathrm{m}^{2}$. Hal ini mungkin disebabkan karena perbedaan konsentrasi flavonoid (polifenol) yang terdapat pada ekstrak buah lerak $0,01 \%$, larutan cabai rawit dan kopi Aceh Ulee Kareng. Semakin tinggi konsentrasi flavonoid (polifenol) semakin menurunkan kekuatan impaknya. Shen menyatakan bahwa fenol dengan konsentrasi $5 \%$ bila berkontak dengan resin akrilik akan merusak permukaan resin akrilik. Dari hasil tersebut maka ada kemungkinan kandungan fenol dalam larutan cabai rawit dan ekstrak rosela lebih kecil dari ekstrak buah lerak $0,01 \%$. Selain itu juga mungkin karena luas permukaan sebagai daerah berdifusi yang lebih kecil pada sampel penelitian yang dilakukan Handayani dkk. dan Diansari dkk. dibandingkan sampel penelitian ini.

Hasil uji LSD pada Tabel 4 menunjukkan adanya perlakuan yang signifikan antar beberapa kelompok, yaitu kelompok $\mathrm{F}$ dan $\mathrm{J}$ dengan nilai $\mathrm{p}=0,008(\mathrm{p}<$ $0,05)$, kelompok $G$ dan $J$ dengan nilai $p=0,009(p<$ $0,05)$. Hasil penelitian ini sama dengan hasil penelitian yang dilakukan Susilaningtyas dkk. yang melakukan perendaman RAPP dalam ekstrak rosela $30 \%$ yang mengandung flavonoid (polifenol) selama 48 dan 96 menit yaitu ada perbedaan pengaruh yang signifikan perendaman ekstrak rosela $30 \%$ terhadap penurunan kekuatan impak dengan nilai $\mathrm{p}=$ $0,002(p<0,05)$. Hal ini sesuai dengan pendapat Soebagio $^{15}$ yang menyebutkan bahwa semakin lama waktu kontak antara resin akrilik dengan flavonoid akan semakin menurunkan kekuatan impak resin akrilik tersebut. ${ }^{15}$

Dapat disimpulkan bahwa ada pengaruh waktu perendaman basis gigitiruan RAPP dalam ekstrak buah lerak $0,01 \%$ selama 2, 3, 4, 5 dan 7 hari terhadap kekuatan impak. Semakin lama waktu perendaman, semakin menurun kekuat-an impak RAPP.

\section{Daftar Pustaka}

1. Carr A B, Browan D T. McCracken's Removable Partial Prosthodontics. $12^{\text {th }}$ ed. Elsevier: Canada, 2011: 2, 107-8.

2. Rathee M, Hooda A, Ghalaut P. Denture hygiene in geriatric persons. http://ispub.com/IJGG/6/1/12364 \#. 5 September 2013.

3. Widyanto, Felicia LI. Pengaruh sinamat aldehid minyak kayu manis terhadap kekuatan impak resin akrilik. Jurnal of Prosthodontics 2010; 1(2): 14-8.

4. Effendi C, Hapsari DN, Putriyanti AR. Pengaruh waktu perendaman resin akrilik heat cured dalam larutan natrium bikarbonat 5\% terhadap kekuatan impak. Majalah Kesehatan FK UB 2012: 1-7.

5. Udarno L, Balittri. Lerak (Sapindus rarak) tanaman industri pengganti sabun. Warta Penelitian dan Pengembangan Tanaman Industri 2009; 15(2): 7-8.

6. Fitrawati J. Efek antifungal berbagai sediaan dari buah lerak terhadap candida albicans. Skripsi. Medan. FKG USU, 2007: 41-3.

7. Aminah SN, Sigit SH, Partosoedjono SS, Rarak D, Metel E. Prostata Sebagai Larvasida Aedes Aegypti. Penelitian PPEK, Badan Penelitian dan Pengembangan Kesehatan, Departemen Ke-sehatan RI, Jakarta. 2010. Cermin Dunia Ke-dokteran. 1-4.

8. Namira U. Pengaruh bahan pembersih klorhek-sidin dan ekstrak buah lerak terhadap jumlah candida albicans pada perendaman resin akrilik polimerisasi panas. Skripsi. Medan. FKG USU, 2013: 18-9, 258,58 .

9. Handajani S, Fitriani D, Tarida M. Pengaruh lama perendaman resin akrilik heat cured dalam jus buah kiwi (actinida deliciosa) terhadap kekuatan impak. Majalah Kesehatan FK UB 2013: 28-34.

10. Sari PV. Pengaruh lama perendaman lempeng resin akrilik heat-cured dalam larutan propolis terhadap kekuatan impak. Journal of Prosthodontics 2010; 1(1): 12-7.

11. Setyohadi R, Wulan KA, Rindy SD. Pengaruh konsentrasi larutan serbuk siwak (salvador persica) sebagai larutan pembersih pada perendaman lempeng resin akrilik heat cured terhadap kekuatan impak. Majalah Kesehatan FK UB 2013: 20-7.

12. Faot F, Panza LHV, Garcia RCMR, et al. Impact and flexural strength, and fracture morphology of acrylic resins with impact modifiers. The Open Dentistry Journal 2009; 3(1): 137-143.

13. Handayani S, Wulan KA, Sari DF. Pengaruh lama perendaman resin akrilik heat cured dalam larutan cabai rawit terhadap kekuatan impak. Majalah Kesehatan FK UB 2013: 28-34.

14. Nirwana I. Kekuatan transversal resin akrilik hybrid setelah penambahan glass fiber dengan metode berbeda. Majalah Kedokteran Gigi (Dent J.) 2005; 38(1): 18.

15. Susilaningtyas W, Faidah, Hutapea ZFRD. Pengaruh lama perendaman resin akrilik heat cured dalam 
ekstrak rosela (hibiscus sabdariffa) terhadap penurunan kekuatan impak. Majalah Kesehatan FK UB 2013: 15-20.
16. Astuty HTI. Perubahan kekerasan resin akrilik heatcured setelah perendaman dalam larutan cuka apel. Skripsi. Medan: Fakultas Kedokteran Gigi Universitas Sumatera Utara, 2010: 12-3,31-9. 